U.D.C. 338.246

A. A. Kuklin

Doctor of Economics, Professor, Institute of Economics, the Ural Branch of Russian Academy of Sciences

\author{
A. E. Zemskov \\ Ph.D. in Economics, Federal Agency for State Reserves
}

N. L. Nikulina

Ph.D. in Economics, Institute of Economics, the Ural Branch of Russian Academy of Sciences

\title{
THEORETICAL AND METHODOLOGICAL APPROACHES TO THE DIAGNOSIS OF THE REGION'S STATE MATERIAL RESERVATION SYSTEM STATUS ${ }^{1}$
}

This paper deals with the structural components of the state reservation theory with the elements of decomposition and tools of studies performed on private lines. A method for diagnosing the state material reservation system (SMRS) as part of economic security in the region is presented. Extensive tests of the methodological apparatus of SMRS assessment on the example of the Ural Federal District have been made.

Keywords: state reservation theory, state material reservation system (SMRS), economic security, SMRS diagnostics technique

The experience of historical development confirms that early establishment of material reserves is an effective means of ensuring economic security of any state. Thus, measures to establish food reserves in Russia, which was often subject to crop failures and famine, go back in history. The completion of a unified system of Russian government reserves formation should be attributed only to the 40th years of the XX century [2].

It should be noted that previously only war and manifestations of the elemental forces of nature were considered to be emergency situations, but now economic risks and technogenic or man-made disasters were added to the list. Each such situation requires very quick concentration of large amounts of a variety of materials (raw materials) and finished products. The state reservation system must ensure, firstly, the immediate needs of the population, and, secondly, the activities of the emergency forces until the time when the industry and agriculture will be able to normalize their work, and, thirdly, resource emergencies during and after disasters such as earthquakes, floods, droughts and poor harvests, large forest fires and so on.

\footnotetext{
${ }^{1}$ The study was carried out with financial support from Russian Humanitarian Science Foundation (project №11-02-00531a «Nonlinear dynamics of socio-economic systems development: diagnosis, modeling, projection») and the target UB RAS program of interdisciplinary projects support carried out in collaboration with scientists of the SB and the FEB in terms of project №09 C-6-1001, «Diagnosis of condition, modeling and projection of development trends of Russian regions until 2030».
}

A necessary and sufficient reserve for the operation and development of the region is a major factor in ensuring its economic security.

Under the State Reservation we understand a system of economic and institutional relations of short-, medium- and long-term measures to ensure the economic security of the country and its regions in a variety of adverse conditions, resulting in:

- enhancing the territorial independence level from the influence of internal and external destabilizing factors (economic, financial crises, changes in energy prices, the possibility of military confrontation, disaster relief etc.) and assess their risks;

- forming the foundations of the country's defensive capacity and potential;

- effective and sustainable development of economic complex;

- maintaining the achieved level and quality of life and providing their further increase;

- implementing material assistance in emergency situations of natural and man-made character, both in Russia and abroad.

SMRS includes the following interrelated and interdependent components: economy - human - natural environment - necessary and sufficient provision for their functioning and development. This system has the ability to respond to short-, medium- and long-term fluctuations in the economy and consider the risks of adverse factors. 
Structural components of the state reservation theory

\begin{tabular}{|c|c|c|}
\hline Components of the theory & Component decomposition & Tools of knowledge, used and proposed for future research \\
\hline $\begin{array}{l}\text { Threats to economic } \\
\text { security that dictate } \\
\text { the objective need to } \\
\text { accumulate, maintain, and, } \\
\text { if necessary, to use the } \\
\text { public reserves }\end{array}$ & $\begin{array}{l}\text { Budget deficit. } \\
\text { The value of the external state, } \\
\text { public corporations and private } \\
\text { organizations debt. } \\
\text { Fluctuations in commodity prices } \\
\text { and food prices. } \\
\text { Natural and man-made disasters } \\
\text { and emergencies. } \\
\text { Military threats, the need for } \\
\text { mobilization reserves preparation. } \\
\text { International economic and } \\
\text { financial crises }\end{array}$ & $\begin{array}{l}\text { Analysis of the economic security condition in the Russian } \\
\text { regions: conceptions and institutional consolidation. } \\
\text { Theoretical and methodological problems of providing } \\
\text { economic security in the Russian regions. } \\
\text { Formation and managing the economic security provision } \\
\text { system in the region. } \\
\text { Monitoring of the economy development indicators. } \\
\text { Control of the external debt indicators of economic objects } \\
\text { and subjects. } \\
\text { Projection of the probability and volumes of natural and } \\
\text { man-made disasters and emergencies. } \\
\text { Projection of military conflicts and adversarial positions } \\
\text { probability }\end{array}$ \\
\hline $\begin{array}{l}\text { Systemic approach to state } \\
\text { reserves (creation of SMRS, } \\
\text { state material reservation } \\
\text { system) }\end{array}$ & $\begin{array}{l}\text { Gold and forex reserves (including } \\
\text { reserves of metals of value). } \\
\text { Fiscal reserves. } \\
\text { Material reserves. } \\
\text { Reserves of natural resources }\end{array}$ & $\begin{array}{l}\text { Comparative analysis of reservation principles in technical } \\
\text { and economic systems. } \\
\text { Logistics (movement of material flows) } \\
\text { Local knowledge on industrial, emergency and military } \\
\text { reserves. } \\
\text { Studies related to the possibility of extensive demand for } \\
\text { reserves from the innovators (innovational enterprises). } \\
\text { Creating favourable conditions for investments. } \\
\text { Monitoring }\end{array}$ \\
\hline $\begin{array}{l}\text { Managing the processes of } \\
\text { accumulation, distribution, } \\
\text { conservation and usage } \\
\text { of government reserves in } \\
\text { order to ensure economic } \\
\text { security }\end{array}$ & $\begin{array}{l}\text { Management tasks. } \\
\text { Management structure. } \\
\text { Management activity schemes. } \\
\text { Subjects of management. } \\
\text { Forms of management. } \\
\text { Means of control. } \\
\text { Management arrangements }\end{array}$ & $\begin{array}{l}\text { Economic-mathematical modeling of functioning conditions } \\
\text { for the organizational structures of the state reservation } \\
\text { system. } \\
\text { Method of horizontal concordance of the decisions while } \\
\text { managing the state reserves. } \\
\text { Methods of the material value volumes accumulation in the } \\
\text { state material reserve. } \\
\text { Methodological basics of managing the system of state } \\
\text { material reserve functional steadiness. } \\
\text { Analysis of foreign processes management experience } \\
\text { in creation and usage of state material reserves to ensure } \\
\text { economic security. } \\
\text { The mechanism of state material reserve resources utilization } \\
\text { as an instrument of ensuring economic security. } \\
\text { The mechanism of state reserves usage to quell inflation }\end{array}$ \\
\hline $\begin{array}{l}\text { Adversarial position to the } \\
\text { destructive phenomena } \\
\text { inside the reservation } \\
\text { system itself }\end{array}$ & $\begin{array}{l}\text { Providing security of reserves } \\
\text { keeping. } \\
\text { Well-timed replenishment of the } \\
\text { reserves }\end{array}$ & $\begin{array}{l}\text { Estimates of the own economic security level of the state } \\
\text { material reserves system. } \\
\text { Development of mechanisms to ensure own security }\end{array}$ \\
\hline
\end{tabular}

This table shows the structural components of state reservation theory with the elements of decomposition and tools of studies performed on private lines. At the present time, the theory of the state reservation should be based on optimal movement and accumulation of reserve value, not only on its real (material) forms. Thus the real form of the reserve is also important - the system to accumulate reserves as the cost of poor quality materials, components, products, etc. loses its pace of development as it will be forced to expend undue efforts to transform the value of the reserve in the right quality at the right time.
A separate block in Figure 1 presents the rates of the state reservation system, which, according to the opinion of the authors, should be incorporated into the system of parameters defining economic security in the region on the rights of an independent element.

The essence of SMRS security is implemented in the system of corresponding indicators. The security assessment is carried out by comparing indicator values with their threshold levels, which characterize the transition from normal into the pre-crisis or crisis zone. Comparison of the indicators with their threshold values gives an opportunity to get the summary picture of SMRS condition and to fo- 
cus on the operational impact to restore the normal situation.

The developed technique is used to monitor the status of SMRS, to estimate the degree of various security threats, to neutralize the action of negative factors and to prevent the emergence of new ones; it also helps to create an effective management system.

\begin{tabular}{|c|c|}
\hline $\begin{array}{l}\text { Block №1 } \\
\text { Economic indicators describing the basic } \\
\text { features and trends of regional economy } \\
\text { development } \\
\text { volume of gross regional product (GRP); } \\
\text { share of defense expenses etc. In the amount of } \\
\text { GRP }\end{array}$ & $\begin{array}{l}\text { Block No } 2 \\
\text { Particular social and economic indicators } \\
\text { gross grain harvest; } \\
\text { share of investments into the fixed capital and expenditures on } \\
\text { science in the amount of GRP; } \\
\text { share of machinery, metal processing and innovative products in } \\
\text { total volume of industrial output; } \\
\text { percentage of citizens with incomes below the subsistence } \\
\text { minimum in the total population of the region; } \\
\text { level of unemployment, the decile coefficient of differentiation, etc. }\end{array}$ \\
\hline \multicolumn{2}{|c|}{ The parameters of indicators of economic security in the region } \\
\hline $\begin{array}{l}\text { Block № } 3 \\
\text { Indicators of the functional and } \\
\text { industry-specific level } \\
\text { level of monetization; budget deficit of } \\
\text { the regional government, inflation rate; } \\
\text { volume of gold reserves; } \\
\text { share of food received on imports in the } \\
\text { total amount of food resources, etc. }\end{array}$ & $\begin{array}{l}\text { Block No } 4 \\
\qquad \text { SMRS indicators } \\
\text { ratio of actual reserves of material values to the normative (scheduled) } \\
\text { inventory; } \\
\text { level of wear of fixed assets (basic production assets) of SMRS; } \\
\text { relative summary amount of imposed fines; } \\
\text { relative summary amount of late fines, penalties for evasion, delay, short } \\
\text { supply, etc. from suppliers; } \\
\text { ratio of substantial and announced budget funds for state reserves; } \\
\text { ratio of expenses on production, refreshment and replacement of } \\
\text { property to the amount of the assigned budget funds for this purpose, } \\
\text { etc. }\end{array}$ \\
\hline
\end{tabular}

Fig. 1. Schematic representation of blocks of economic security indicators based on SMRS

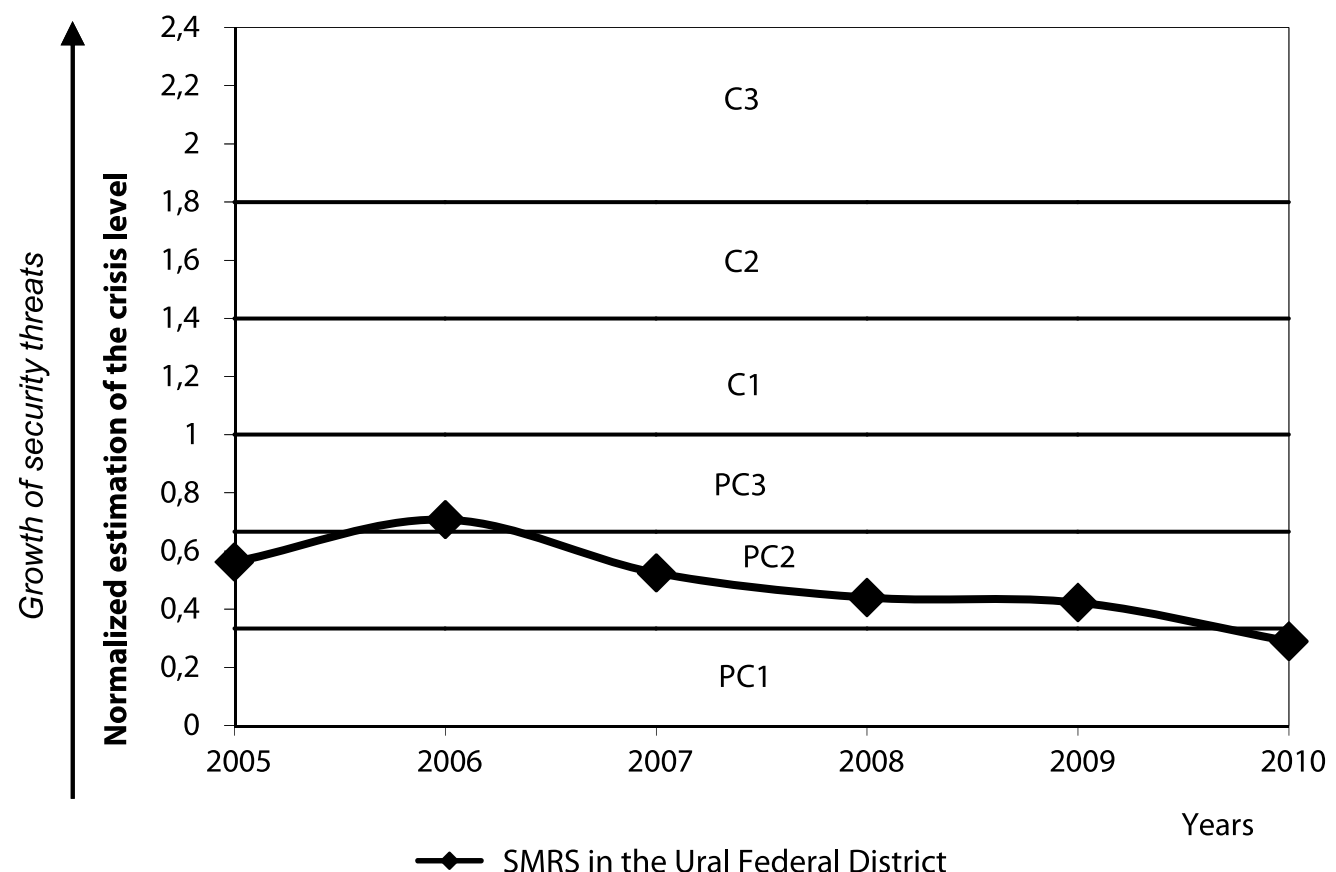

Note. Designation of security conditions: $N$ - normal (corresponds with zero pre-crisis and crisis levels, not present in the figure); PC1 - initial pre-crisis condition; $P C 2$ - developing pre-crisis condition; PC3 - critical pre-crisis condition; C1 - unstable crisis condition; C2 - threatening crisis condition; $\mathrm{C} 3$ - emergency crisis condition

Fig. 2. The dynamics of change in SMRS state in the Ural Federal District in general, 2005-2010 
Based on analysis of the current state reservation system and threats to its security, four indicative blocks were formed:

1. Block of inventories supply and implementation.

2. Block of the state reserves status and material base development.

3. Block of state government reserves management efficiency.

4. Block of finances.

The values of indicative indicators presented in Figure 1, determine the nature of the situation on the corresponding blocks of the state material reservation.

In accordance with the methodological apparatus of the Institute of Economics, the Ural Branch of RAS [3], three main states of the considered territory were identified in terms of security of state reserves: normal, pre-crisis and crisis. Threshold levels on performance indicators are established to distinguish between these three states, the methods of expert and discriminant analysis are used $[1,3]$.
As part of the developed technique, diagnostics of SMRS in the Ural Federal District was performed (Fig. 2).

It is obvious from the calculated values of the SMRS state in the Ural Federal District, that in 2006 the situation was assessed as pre-crisis (critical). In 2007-2010, some improvement of SMRS in the UFD is diagnosed and the transition to the initial pre-crisis state is observed.

Usage of the indicative analysis makes it possible to diagnose the status of the state reservation system and to evaluate its impact on economic security in the region plus also makes it possible to compare the state systems of material reserve on separate territories.

Diagnosis of the SMRS security is necessary for assessment of the possible crisis situations and for ensuring the readiness of state material reserves, classification of territories by levels of the SMRS security, development of program-target activities to ensure reliable public material reserves and determination of the extent of the SMRS security threats.

\section{References}

1. Ayvazyan S. A., Bezhaeva Z. I., Staroverov D. V. Klassifikatsiya mnogomernykh nablyudeniy [Classification of multidimensional observations]. Moscow, 1974, 240 p.

2. Grigor'ev A. A., Gasumyanov V. I. Istoriya gosudarstvennykh rezervov Rossii. S IX veka po 1917 god [History of the Russian state reserves. Since IX century to 1917]. - Saint Petersburg, 2003, 480 p.

3. Kompleksnaya metodika diagnostiki ekonomicheskoy bezopasnosti territorial'nykh obrazovaniy RF / A. I. Tatarkin (i dr.) [A comprehensive technique for diagnosing the economic security of territorial entities of the Russian Federation]. - Ekaterinburg, 2001.

\section{Information about the authors}

Kuklin Aleksandr Anatol'evich (Ekaterinburg) - Doctor of Economics, Professor, Head of the Center for Economic Security, Institute of Economics, the Ural Branch of Russian Academy of Sciences (620014, Ekaterinburg, Moskovskaya St. 29, e-mail: alexkuklin49@mail.ru)

Zemskov Aleksandr Efimovich (Moscow) - Ph.D. in Economics, Deputy Head of the Federal Agency for State Reserves (109012, Moscow, B. Cherkassky per., 6/7).

Nikulina Natal'ya Leonidovna (Ekaterinburg) - Ph.D. in Economics, research scientist of the Center for Economic Security, Institute of Economics, the Ural Branch of Russian Academy of Sciences (620014, Ekaterinburg, Moskovskaya St. 29, e-mail: nikulinanl@mail.ru). 